\title{
Vegetation Restoration Alleviated the Soil Surface Organic Carbon Redistribution in the Hillslope Scale on the Loess Plateau, China
}

\author{
Yipeng Liang ${ }^{1,2}$, Xiang $\mathrm{Li}^{1,2}$, Tonggang Zha ${ }^{1,2,3 *}$ and Xiaoxia Zhang ${ }^{1,4}$ \\ ${ }^{1}$ School of Soil and Water Conservation, Beijing Forestry University, Beijing, China, ${ }^{2}$ Key Laboratory of Soil and Water \\ Conservation and Desertification Combating, State Forestry and Grassland Administration, Beijing Forestry University, Beijing, \\ China, ${ }^{3}$ Jixian National Forest Ecosystem Research Network Station, CNERN, Beijing Forestry University, Beijing, China, ${ }^{4}$ The \\ Third Construction Co., Ltd. of China Construction First Group, Beijing, China
}

\section{OPEN ACCESS}

Edited by:

Jesús Rodrigo-Comino,

Universität Trier, Germany

Reviewed by: Mahboobeh Kiani-harchegani,

Yazd University, Iran

Safwan Mohammed,

University of Debrecen, Hungary

*Correspondence:

Tonggang Zha

zhtg73@bju.edu.cn

Specialty section:

This article was submitted to

Soil Processes,

a section of the journal

Frontiers in Environmental Science

Received: 07 October 2020

Accepted: 18 December 2020

Published: 27 January 2021

Citation:

Liang Y, Li X, Zha T and Zhang X (2021)

Vegetation Restoration Alleviated the Soil Surface Organic Carbon Redistribution in the Hillslope Scale on

the Loess Plateau, China.

Front. Environ. Sci. 8:614761.

doi: 10.3389/fenvs.2020.614761
The redistribution of soil organic carbon (SOC) in response to soil erosion along the loess slope, China, plays an important role in understanding the mechanisms that underlie SOC's spatial distribution and turnover. Consequently, SOC redistribution is key to understanding the global carbon cycle. Vegetation restoration has been identified as an effective method to alleviate soil erosion on the Loess Plateau; however, little research has addressed vegetation restoration's effect on the SOC redistribution processes, particularly SOC's spatial distribution and stability. This study quantified the SOC stock and pool distribution on slopes along geomorphic gradients in naturally regenerating forests (NF) and an artificial black locust plantation (BP) and used a corn field as a control (CK). The following results were obtained: 1) vegetation restoration, particularly NF, slowed the migration of SOC and reduced the heterogeneity of its distribution effectively. The topsoil SOC ratios of the sedimentary area to the stable area were 109\%, 143\%, and $210 \%$ for NF, BP, and CK, respectively; 2) during migration, vegetation restoration decreased the loss of labile organic carbon by alleviating the loss of dissolved organic carbon (DOC) and easily oxidized organic carbon (EOC). The DOC/SOC in the BP and NF increased significantly and was 13.14 and 17.57 times higher, respectively, than that in the $\mathrm{CK}(p<0.05)$, while the EOC/SOC in the BP and NF was slightly higher than that in the CK. A relevant schematic diagram of $\mathrm{SOC}$ cycle patterns and redistribution along the loess slope was drawn under vegetation restoration. The results suggest that vegetation restoration in the loess slope, NF in particular, is an effective means to alleviate the redistribution and spatial heterogeneity of SOC and reduce soil erosion.

Keywords: vegetation restoration, soil organic carbon stability, hillslope, soil erosion, Loess Plateau (China)

\section{INTRODUCTION}

Soil is considered the most significant terrestrial carbon sink. It is a critical factor in the regulation of the global carbon cycle, as well as in the supply of pivotal ecosystem services (Muñoz-Rojas et al., 2016; Pereira et al., 2018; Brevik et al., 2020). Soil organic carbon (SOC) is the amount of organic carbon contained in the soil fraction and contributes to a variety of important biological, physical, and chemical functions (Muñoz-Rojas et al., 2016; Willaarts et al., 2016; Wiesmeier et al., 2019; 
Pereira et al., 2020). SOC's depletion has a negative influence on water storage capacity, soil fertility, and the supply of other significant ecosystem services, such as climate regulation, and is therefore a major factor that leads to soil degradation (KianiHarchegani and Sadeghi, 2020). In water-limited ecosystems, vegetation restoration is one of the options to prevent land degradation and soil erosion (Yu et al., 2016; Shi et al., 2019a). Ongoing vegetation restoration and climate change processes are having a far-reaching effect on soil carbon stocks, which creates an imbalance in carbon input/output ratios and results frequently in net releases back into the atmosphere (Haigh et al., 2019; Petrakis et al., 2020; van der Bank and Karsten, 2020). SOC is the most susceptible to changes in site conditions and is therefore the target of most evaluations (García-Díaz et al., 2016; Yeasmin et al., 2020).

In past years, numerous estimates of SOC stocks have been conducted at multiple scales (from slope to watershed, regional and global), using different approaches (Abdalla et al., 2018; ÁlvaroFuentes et al., 2014; Grebliunas et al., 2016; García-Díaz et al., 2018; Shi et al., 2019b; Rodrigo-Comino et al., 2020). Quantitative assessments of the redistribution of SOC along geomorphic gradients and the processes involved have become increasingly important in a changing climate (Bloom et al., 2016; Yu et al., 2019a; Olson and Gennadiev, 2020). At the same time, the storage of SOC showed significant differences within ecological units because of the effect of such local factors as soil properties, topographic conditions, soil depth, and land use and management (Novara et al., 2019). Among these, topography is one of the five major soil surface formation factors (Jenny, 1994). Topography affects soil erosion and thus affects SOC's spatial distribution either directly or indirectly (Sun et al., 2010; Rodrigo-Comino et al., 2016, 2017; Cagnarini et al., 2019; Cerdà and Rodrigo-Comino, 2020). Several studies have demonstrated the effects of topography and soil erosion on SOC's distribution (Beguería et al., 2015). For example, a previous study reported a close relationship between soil erosion and SOC content and indicated further that the SOC content is generally higher in a slope's middle and lower reach than in the upper reach (Sanderman and Chappell, 2013; Hancock et al., 2019). A typical hill slope can be divided into a stable area, eroding area, and sedimentary area according to its position and gradient on the slope (Wang et al., 2014a; Wang et al., 2017). Topography affects the stable area less, but the SOC in the eroding area will continue to migrate toward the sedimentary area, where it will accumulate (Doetterl et al., 2016). At the same time, the slope system also affects the composition and stability of SOC (Wang et al., 2014b; Wiaux et al., 2014). In some simulations in hillslope plots, the distribution of labile organic carbon varied markedly along slopes (Berhe and Torn, 2017), and most followed the trend: sedimentary area $>$ stable area $>$ eroded area (Doetterl et al., 2012; Patton et al., 2019; Wang et al., 2019). However, current research on the distribution of the SOC in the extension of slopes focuses primarily on agricultural land or grassland (Kirkels et al., 2014; Doetterl et al., 2016; Li et al., 2019). Vegetation restoration is recognized widely as an effective way to enhance SOC content and control soil erosion (Kim and Kirschbaum, 2015; Xin et al., 2016; Hancock et al.,2019). Therefore, it seems likely that vegetation restoration may also affect the SOC redistribution process in areas with complex terrain.
The Chinese Loess Plateau covers approximately $64 \times$ $10^{4} \mathrm{~km}^{2}$, lies in the semiarid zone of China, and is characterized by thick $(50-300 \mathrm{~m})$, yet highly erodible soil (Feng et al., 2013). Hundreds of years of intensive cultivation and severe erosion have incised the plateau and thus fragmented the vast flat area into tableland and slopes, with notable depositions in valley bottoms (Wang et al., 2017; Yu et al., 2019b). To alleviate soil erosion, large-scale ecological restoration efforts have been implemented in the Loess Plateau, the most notable example of which is the Grain for Green Project (GGP) that was initiated in the 1980s (Feng et al., 2013; Yu et al., 2020a). These projects have improved vegetation restoration greatly and affected SOC sequences and the carbon cycle on the Loess Plateau (Chang et al.,2011; Ran et al., 2013; Wang et al., 2017). However, systematic investigations of the results of vegetation restoration on SOC redistribution and its stability have not been reported to date. Particularly, the topographic positions of SOC in the hilly-gully region on the fragmented Loess Plateau remain unknown.

To offer new insights to fill this gap, hillslope positions and vegetation-induced changes in SOC in the first $0-30 \mathrm{~cm}$ were investigated on three different hillslopes of the loess hilly watershed where farmland has been transformed into forestland. Accordingly, this study's primary goals were to 1 ) detect changes in SOC at different soil depths $(0-10,10-20$, and $20-30 \mathrm{~cm})$ and different vegetation types at the hillslope scale and 2) assess the effects of vegetation species and topography on soil carbon stability during ecological restoration. Our study hypothesized that vegetation restoration alleviates the spatial heterogeneity of SOC by increasing organic input and decreasing soil erosion and the slow SOC mineralization or loss of unstable carbon.

\section{MATERIALS AND METHODS}

\section{Study Area}

As a typical loess gully area, the Caijiachuan Watershed $\left(110^{0} 27^{\prime}\right.$ $111^{0} 07^{\prime} \mathrm{E}, 35^{0} 53^{\prime}-36^{0} 21^{\prime} \mathrm{N}$, elevation $868-1553 \mathrm{~m}$ ) is located on the Loess Plateau in Ji County, Shanxi province, China (Figure 1). This area has a warm, temperate continental climate with an average mean temperature of $10^{\circ} \mathrm{C}$, a mean duration of $2,563 \mathrm{~h}$ of sunshine, a frost-free period of 172 days, and a mean annual precipitation of $575.9 \mathrm{~mm}$. The precipitation varies greatly between years and seasons and is concentrated largely between June and September of each year (Zhou et al., 2013). The study area is characterized by a deeply incised hilly-gully loess landscape. The soils are the result of a high wind-deposited loess process and can be classified as Haplic Luvisols (IUSS Working Group, 2006).

In general, soils are characterized by a high content of sand (45-60\%) and silt (36-55\%) material with certain variations depending on the hillslope position and previous land uses (Zhang et al., 2013b). The soil bulk density is approximately $1.15-1.30 \mathrm{~g} \mathrm{~cm}^{-3}$, with a low organic matter content $\left(5-15 \mathrm{~g} \mathrm{~kg}^{-1}\right)$. The principal forest types are naturally regenerating forests (NF) dominated by aspens (Populus davidiana) and oaks (Quercus liaotungesis) and reforested areas of black locust (Robinia pseudoacacia), Chinese pine (Pinus 


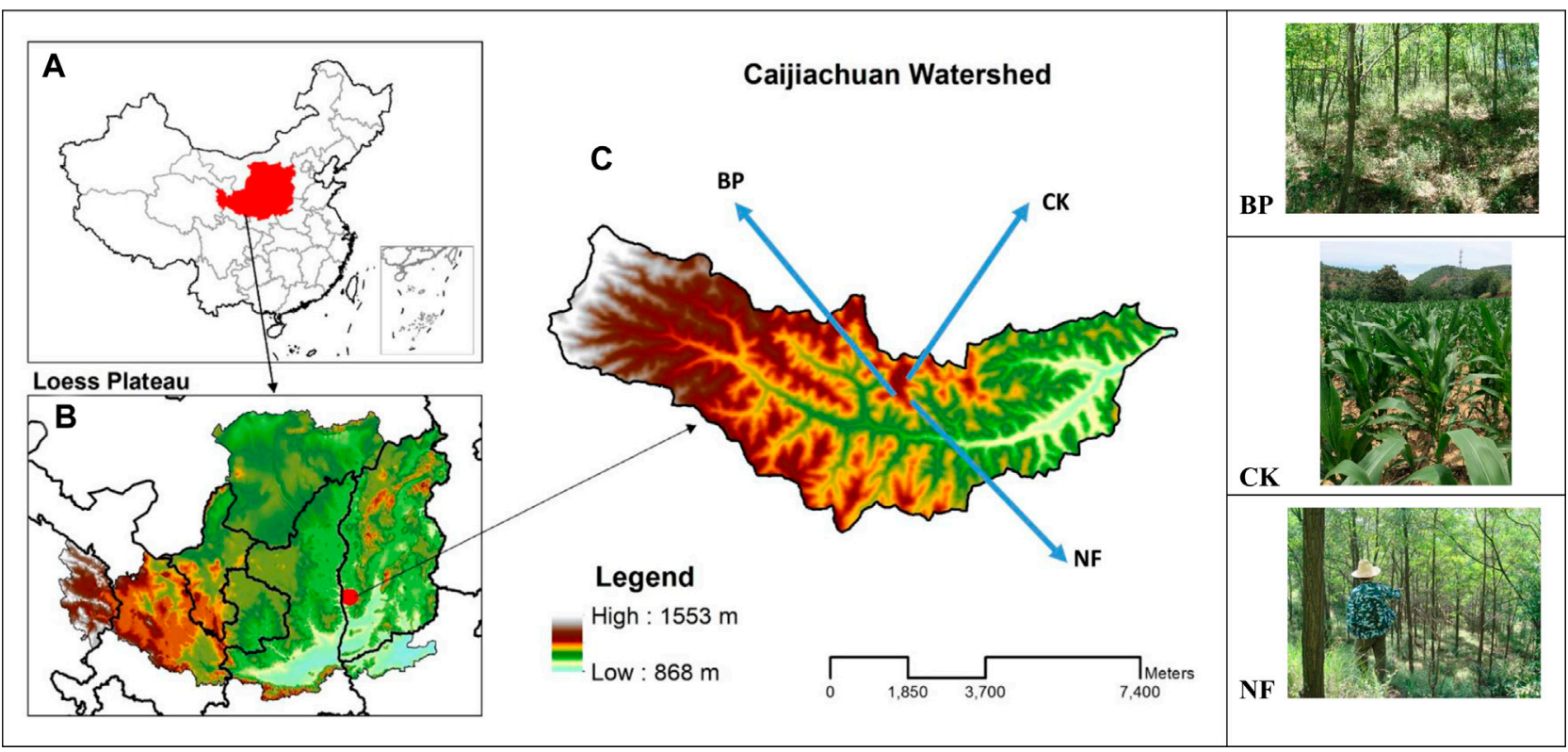

FIGURE 1 | Locations of the research sites (a: China, b: Shanxi Province, and c the Caijiachuan Watershed). NF is the naturally regenerating forest, BP is the black locust plantation, and CK is the cropland as control.

TABLE 1 | Basic information on the research site (Caijiachuan catchment, Shanxi Province, North China). DBH = diameter at breast height; canopy density is provided for the forested sites and coverage is provided for the corn farmland; "-" = not measured. The values presented are the means and SD in brackets.

\begin{tabular}{|c|c|c|c|c|c|c|c|c|}
\hline $\begin{array}{l}\text { Vegetation } \\
\text { type }\end{array}$ & $\begin{array}{l}\text { Slope } \\
\text { length } \\
\text { (m) }\end{array}$ & $\begin{array}{c}\text { Slope } \\
\text { angle } \\
\left({ }^{0}\right)\end{array}$ & $\begin{array}{c}\text { Slope } \\
\text { aspect }\end{array}$ & $\begin{array}{l}\text { Altitude } \\
\text { (m) }\end{array}$ & DBH (cm) & $\begin{array}{c}\text { Tree } \\
\text { height } \\
(\mathrm{m})\end{array}$ & $\begin{array}{c}\text { Tree } \\
\text { density } \\
\left(\mathrm{hm}^{-2}\right)\end{array}$ & $\begin{array}{c}\text { Canopy } \\
\text { density/coverage } \\
(\%)\end{array}$ \\
\hline $\begin{array}{l}\text { Black locust } \\
\text { plantation }\end{array}$ & 281 & 19 & South & 1120 & $11.48(0.26)$ & $8.39(0.40)$ & $1864(12)$ & $84.6(2.3)$ \\
\hline $\begin{array}{l}\text { Natural } \\
\text { recovery forest }\end{array}$ & 302 & 20 & Southeast & 1040 & $10.96(0.35)$ & $6.68(0.22)$ & $1942(15)$ & $87.3(5.1)$ \\
\hline Corn farmland & 278 & 18 & South & 1120 & - & - & - & $84.5(1.6)$ \\
\hline
\end{tabular}

tabulaeformis), and cypresses (Platycladus orientalis). All forests were planted in 1990 as part of the GGP.

\section{Experimental Design}

Three typical hillslopes characterized by similar landforms (considering the gradient, aspect, and length fully) and different vegetation types (Table 1) were selected, representing 1) a black locust plantation (BP), 2) NF, and 3) a corn field as a control (CK). Both the $\mathrm{BP}$ and NF were converted from corn filed in 1990, and the main tree species in the NF was secondary Quercus aliena Bl. Both the BP and CK are located in the same gully at similar elevations (1120 $\mathrm{m}$ a.s.l.). The NF is located in an area affected by a gully of approximately $4 \mathrm{~km}$ southeast and an elevation of approximately $1040 \mathrm{~m}$ a.s.l. Corn fields in this area adopt the traditional cultivation model with few management measures, such as ploughing and fertilization.

In this study, the hillslopes were divided into three erosional areas based on the slope gradient and soil erosion conditions (Figure 2). Specifically, the stable area was defined as the area at the shoulder of a slope with a low gradient $(<50)$ and light soil erosion marks. The eroding area was defined as the area in the backslope with a steeper gradient $(>100)$ and clearer soil erosion signs. Finally, the sedimentary area was defined as the area at the footslope with a lower gradient $(<50)$. Because the eroded material from the eroding areas is used to accumulate in the sedimentary parts, the soils therein consist largely of a mixture of sediment setting on loess parent materials in deeper layers (Doetterl et al., 2012; Doetterl et al., 2016; Wang et al., 2017).

\section{Field Sampling}

In mid-August, 2017, three plots of $10 \times 10 \mathrm{~m}$ (separated by at least $10 \mathrm{~m}$ ) were established representing the typical erosional area of each typical hillslope. Detailed site conditions (including elevation, slope length, angle, and aspect), as well as a vegetation inventory, were conducted in each plot. Five sampling points were set randomly and soil samples were collected at $10 \mathrm{~cm}$ intervals from a depth of $0-30 \mathrm{~cm}$ using a cylindrical soil driller (4 cm diameter and $20 \mathrm{~cm}$ long). Soil from corresponding layers was mixed to form one soil composite 


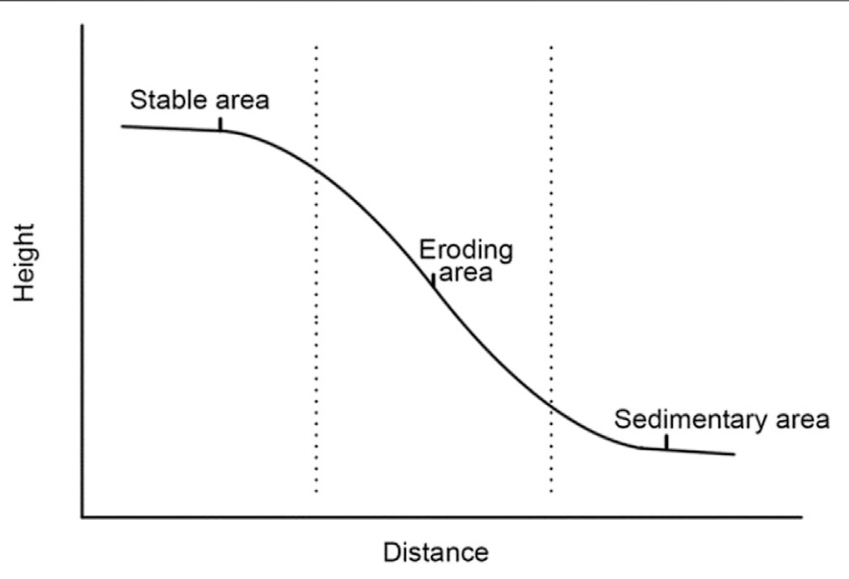

FIGURE 2 | Topographical transect showing stable, eroding, and sedimentary areas. The stable area is on the top of the slope and has a small gradient $\left(<5^{\circ}\right)$ and little erosion. The eroding area is in the middle of the slope and has a steep gradient $\left(>10^{\circ}\right)$ and strong soil erosion. The sedimentary area is at the bottom of a slope and has a small gradient $\left(<5^{\circ}\right)$ and notable sediment deposit.

sample. Five replicate soil samples were collected in each plot, and 135 soil samples were collected in total. Each soil sample was divided evenly into two parts after visible roots and other impurities were removed, and one was naturally air-dried, while the other was refrigerated at $4^{\circ} \mathrm{C}$ until further use.

\section{Laboratory Analysis}

The air-dried soil was passed through a $0.2 \mathrm{~mm}$ sieve to ensure complete removal of gravel. The SOC content was determined by the potassium dichromate external heating method (Bao, 2000). The dissolved organic carbon (DOC) content was analyzed as follows: $10 \mathrm{~g}$ of a soil sample was added to a triangular flask with $40 \mathrm{ml}$ of distilled water. The sample was shocked and leached for approximately $30 \mathrm{~min}$ at room temperature after $10 \mathrm{~min}$ of highvelocity centrifugation $\left(6000 \mathrm{r} / \mathrm{min}\right.$ at $\left.4^{\circ} \mathrm{C}\right)$. The supernatant obtained was filtered through a $0.45 \mu \mathrm{m}$ filter into separate vials and the extracts were analyzed for DOC using a total organic carbon analyzer (Multi N/C 3100, Analytik Jena AG, Thuringia, Germany). The level of easily oxidized organic carbon (EOC) in the organic phases was measured using $333 \mathrm{mmol} / \mathrm{L}$ of $\mathrm{KMnO}_{4}$ by shaking for $1 \mathrm{~h}$, centrifugation for $5 \mathrm{~min}$ at $4000 \mathrm{~g}$, diluting 10 times with deionized water, and using a spectrophotometer (AQ8100, Thermo Scientific ${ }^{\mathrm{TM}}, \mathrm{MA}$ ) to measure the absorbance at $565 \mathrm{~nm}$ (Von Lützow et al., 2007). The $\mathrm{KMnO}_{4}$ standard curve and calculation method were based on Blaire et al. (1995) report.

\section{Statistical Analysis}

An analysis of variance (ANOVA) was used to analyze vegetation restoration's effects on SOC content, DOC/SOC, and EOC/SOC between forest types, slope areas, and soil depth $(p<0.05)$. The means for each vegetation type in Table 1 were calculated by averaging the values of nine plots within the same slope, and the means in the figures for each area were calculated by averaging the values from three replicated plots in the corresponding soil layers. All data analyses were performed using SPSS v. 23.0 (SPSS Inc. 2016; NC) and R software v. 3.6 (R Development Core Team, 2012; R Project for Statistical Computing, Vienna, Austria).

\section{RESULTS}

\section{Effect of Vegetation Restoration on SOC Content}

Figure 3 shows that the SOC content increased significantly in response to vegetation restoration $(p<0.05)$. For the BP, the average SOC content was $6.85 \mathrm{~g} / \mathrm{kg}, 1.38$ times higher than that of the CK. For NF, the average SOC content was $14.28 \mathrm{~g} / \mathrm{kg}$, 2.88 times higher than that of the CK. The SOC content in the same area decreased significantly with increasing soil depth $(p<0.05)$.

The SOC content followed the same distributions throughout the three vegetation types: sedimentary area $>$ stable area $>$ eroding area. However, the range of the changes observed was smaller after vegetation restoration. The ratio of the SOC content in the sedimentary to eroding areas in the CK was $247.0 \%$, which decreased to $158.4 \%$ and $129.3 \%$ in response to the BP and NF, respectively. The change in the SOC distribution along the slope was most obvious in the $0-10 \mathrm{~cm}$ soil layer following vegetation recovery. In $\mathrm{BP}$ and $\mathrm{CK}$, the SOC content in the deposition area was significantly higher than that in both the stable and eroding areas $(p<0.05)$. However, in NF, no significant difference was found in the surface soil between the three areas tested $(p<0.05)$. In the $20-30 \mathrm{~cm}$ soil layer, the SOC contents of NF, BP, and CK were all significantly higher in the deposition area than in the stable area and the content in the stable area was significantly higher than that in the eroding area $(p<0.05)$.

\section{Effects of Vegetation Restoration on SOC Stability Effects on Dissolved Organic Carbon}

The proportion of DOC in SOC increased significantly $(p<$ 0.05 ) after vegetation restoration (Figure 4). The DOC/SOC of the $\mathrm{BP}$ and NF was $0.92 \%$ and $1.23 \%$, respectively, 13.14 times and 17.57 times higher, respectively, compared to the CK 


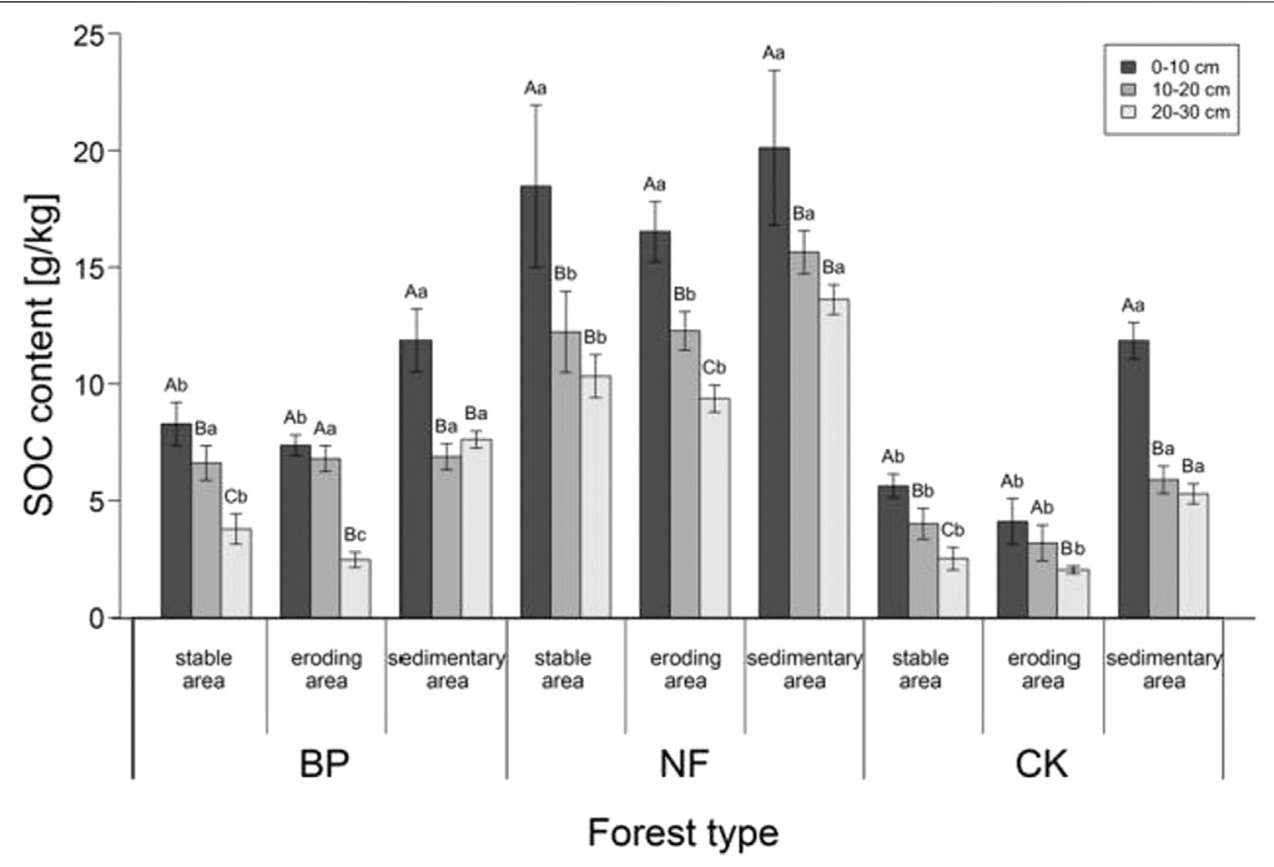

FIGURE 3 | Soil organic carbon content of the 0-30 cm soil layer (in $10 \mathrm{~cm}$ intervals) in the three areas defined in Figure 2 under naturally regenerating forests (NF), black locust plantation (BP), and the corn field as the control (CK). Vertical bars represent the standard deviations of five replicated soil samples. Different capital letters for the same areas indicate significant differences at $p<0.05$ of soil layers, while different lowercase letters for the same soil layers indicate significant differences at $p<0.05$ of different regions.

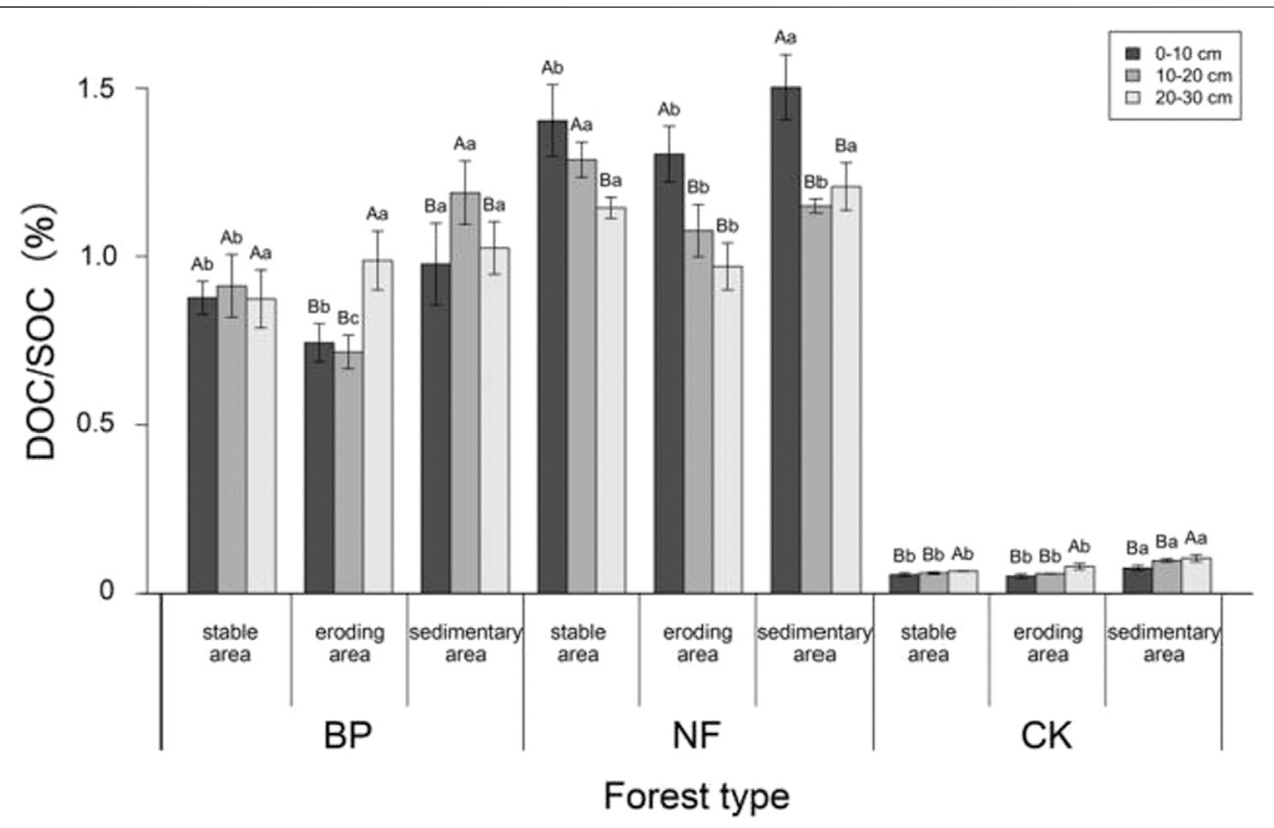

FIGURE 4 | Ratio of dissolved organic carbon (DOC) to total soil organic carbon (SOC) of the 0-30 cm soil layer (in $10 \mathrm{~cm}$ intervals) in three areas under different forest types. Vertical bars represent the standard deviations of five replicated soil samples. Different capital letters for the same areas indicate significant differences at $p<$ 0.05 of soil layers, while different lowercase letters for the same soil layers indicate significant differences at $p<0.05$ of different regions.

(0.07\%). The DOC/SOC differed significantly in different soil layers; however, no consistent pattern of change was identified $(p<0.05)$. In the BP, the DOC fluctuated with the soil layer, but without apparent regularity; in the same area of NF, DOC/ SOC decreased with increasing soil depth but increased in the $\mathrm{CK}$. 


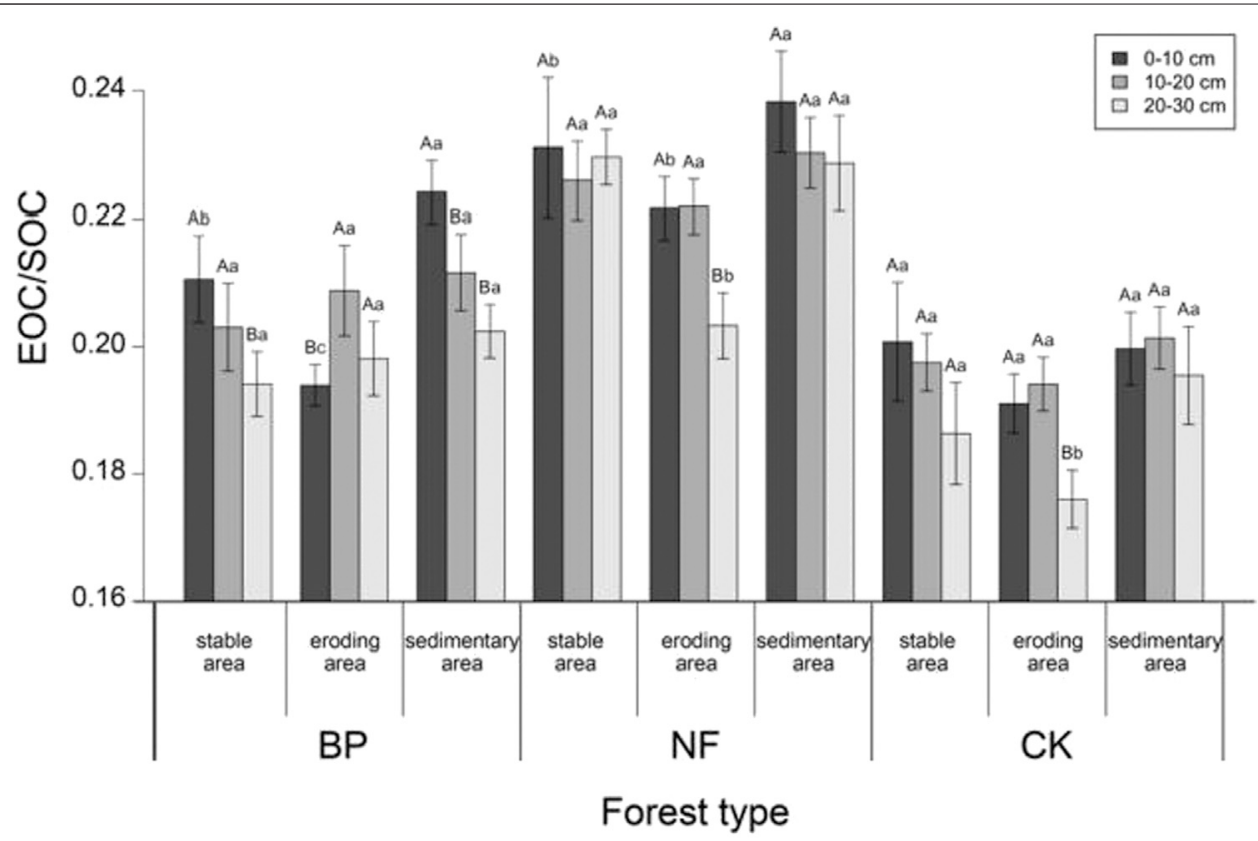

FIGURE 5|Ratio of easily oxidized organic carbon (EOC) to SOC of the 0-30 cm soil layer (in $10 \mathrm{~cm}$ intervals) in the three areas under different forest types. Vertical bars represent the standard deviations of five replicated soil samples. Different capital letters for the same areas indicate significant difference at $p<0.05$ of soil layers, while different lowercase letters of the same soil layers indicate significant differences at $p<0.05$ of different regions.

Compared to the CK, the increasing extent of DOC/SOC in the sedimentary area decreased significantly after vegetation restoration $(p<0.05)$. In the $\mathrm{BP}, \mathrm{NF}$, and $\mathrm{CK}$, the ratios of $\mathrm{DOC} / \mathrm{SOC}$ in the deposition areas were $1.29,1.15$, and 1.50 times that in the eroding area. For the BP, the DOC/SOC in the sedimentary area in the $0-10 \mathrm{~cm}$ and $10-20 \mathrm{~cm}$ soil layers was significantly higher than that in the stable and eroding areas $(p<0.05)$. However, in the $20-30 \mathrm{~cm}$ soil layer, no significant difference was found between the deposition and eroding areas $(p<$ 0.05 ), and in NF, no significant erosion or accumulation of DOC in a specific area was observed $(p<0.05)$. In the CK, the DOC/SOC of each soil layer in the deposition area was significantly higher than that in both the stable and eroding areas $(p<0.05)$.

\section{Effects on the Easily Oxidized Organic Carbon}

Figure 5 shows that the increase in EOC/SOC following vegetation restoration was not significant $(p<0.05)$. The average EOC/SOC values of the BP and NF were $20.52 \%$ and $22.56 \%$, respectively, approximately 1.06 and 1.16 times higher than that of the CK (19.38\%). The EOC/SOC in both the stable and sedimentary areas decreased with increasing soil depth; however, no regular change was identified in the eroding area. No significant difference was found between different soil layers in any of the three regions $(p<0.05)$.

Among the three vegetation types, the EOC/SOC ratio was slightly, but not significantly, lower in the eroding area than the stable area, and the EOC/SOC in the deposition area was identical to that in the stable area $(p<0.05)$. Vegetation restoration did not affect this result significantly $(p<0.05)$. The ratios of EOC/SOC in the sedimentary areas of the $\mathrm{BP}, \mathrm{NF}$, and CK were $1.06,1.08$, and 1.06 times higher, respectively, than that in the eroding area. The
EOC/SOC of the $0-10 \mathrm{~cm}$ layer in the BP and NF was significantly higher than that in the eroding area $(p<0.05)$; however, in the $10-20 \mathrm{~cm}$ and the $20-30 \mathrm{~cm}$ soil layers, there were no significant $(p<0.05)$ differences among the three areas. The CK showed no significant difference between soil layers $(p<0.05)$.

\section{DISCUSSION}

\section{Effect of Vegetation Restoration on SOC Migration at the Soil Surface $(0-30 \mathrm{~cm})$}

Soil erosion and SOC deposition along hillslopes can lead to spatial redistribution of SOC, i.e., the removal of soils that are rich in organic carbon from source hillslopes (shoulder and backslope) and their accumulation at the footslope (Wang et al., 2017). It has been confirmed that the SOC content in the cultivated areas of the Loess Plateau had the following distribution pattern: sedimentary area $>$ stable area $>$ eroded area (Wang et al., 2014a; Li et al., 2019). In our study, considering the first $30 \mathrm{~cm}$, the SOC distribution along the hillslope after vegetation restoration followed a similar trend. However, the ratio of SOC content in the sedimentary area to the eroded area decreased significantly $(p<0.05)$. This could indicate that vegetation restoration reduced the migration of SOC effectively in some areas. Further, while vegetation recovery increased the SOC input, it decreased soil erosion effectively (Wang et al., 2011; Qin et al., 2014). This could also explain the fact that the SOC among these three areas of the $0-10 \mathrm{~cm}$ soil layer after vegetation recovery decreased significantly; at the same time, the change was not significant in the $20-30 \mathrm{~cm}$ soil layer $(p<0.05)$. Further, in NF, the surface SOC did not differ 

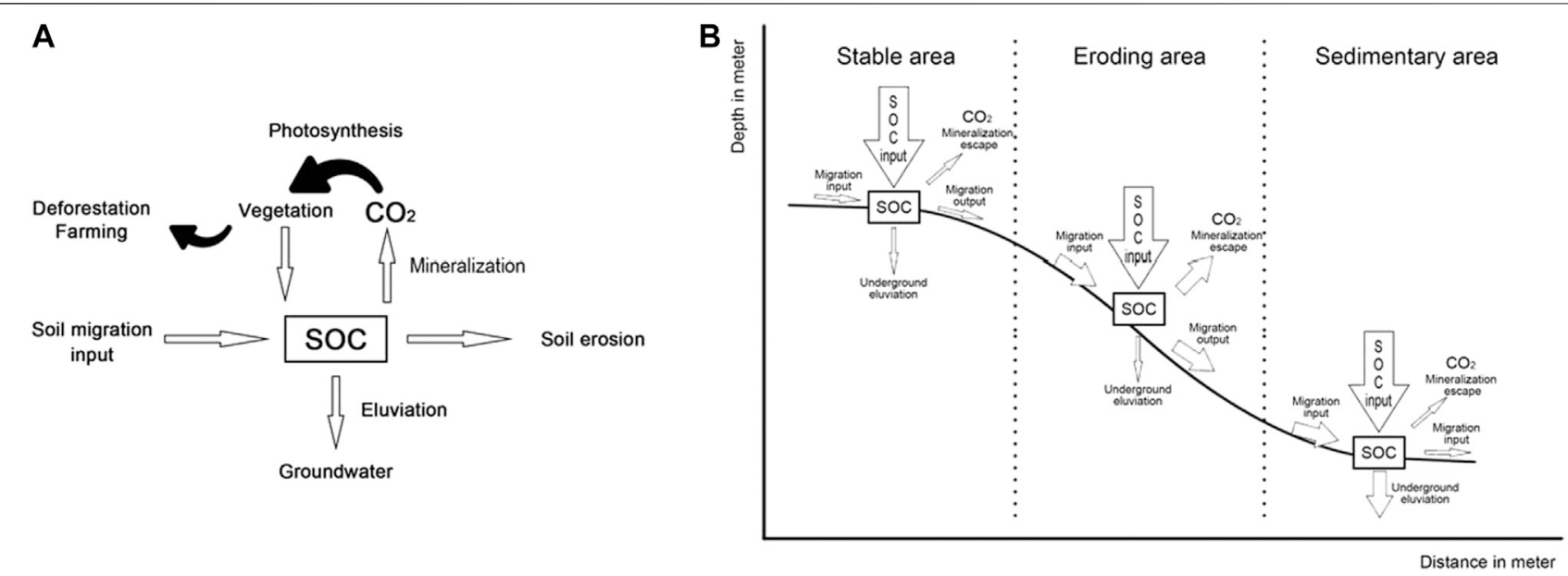

FIGURE 6 | (A) SOC cycle pattern. SOC reserves depend mainly on a dynamic balance between input and output. For SOC in a certain area, SOC input includes largely soil migration input because of soil erosion and organic carbon contained in the vegetation litter; SOC output includes largely soil migration output because of soil erosion, mineralization, and dissolution of active parts of SOC. The carbon dioxide $\left(\mathrm{CO}_{2}\right)$ in the atmosphere is fixed by photosynthesis to achieve carbon circulation. (B) SOC migration pattern in stable, eroding, and sedimentary areas along the slopes in response to vegetation restoration. The thickness of the arrows indicates the amount of SOC migration.

significantly between different areas, and thus, NF could be considered to perform better in reducing SOC heterogeneity. This could be the case because the $\mathrm{BP}$ vegetation types were relatively simple over time and their diversity recovery was slower than that of NF (Zhang et al., 2017). This led indirectly to a low root density in the surface soil and a small cumulative amount of litter on the surface (Ceccon et al., 2011; Vos et al., 2019). Therefore, the resulting soil erosion-inhibiting effects were weaker in the BP than in NF.

With respect to the sampling depth, we cannot assume that the SOC concentration below $30 \mathrm{~cm}$ was unimportant. Therefore, future research should be devoted to assessing the effects that the tree roots, root secretions, and the microorganisms associated with them may affect, which, subsequently, enrich the SOC pool themselves. Secondly, it would be possible to observe whether dissolved SOC migrates deep into the soil. Finally, soil organisms have a very large effect (direct and indirect) on the distribution of SOM in soil (also at a depth of over $30 \mathrm{~cm}$ ). This is particularly common in soils developed on loess and is associated particularly with earthworms (anecic earthworms) (Lavelle, 1988).

\section{Effect of Vegetation Restoration on the Stability of SOC on Hillslopes}

It is accepted generally that DOC, microbial biomass carbon, EOC, and particulate organic carbon are the most active parts of SOC (Von Lützow et al., 2007; Wang et al., 2014b). These indices reflect small changes in the soil before it experiences changes in the total organic carbon (Bloom et al., 2016; Yu et al., 2020b). EOC and DOC were considered the most sensitive indicators of labile organic carbon in response to changes in vegetation areas (Haynes, 2005; Zhang et al., 2013a). Hence, EOC/SOC and DOC/SOC were chosen to evaluate vegetation restoration's effects on SOC stability.
Generally, DOC originates from plant litter, microbial decomposition, and root exudation (Franzluebbers, 2002). Although the DOC content is very low, it has strong mobility in the soil and therefore is considered one of the main forms of soil nutrient loss (Perakis and Hedin, 2002; Zhang et al., 2003). In this study, the increment in DOC/SOC in the sedimentary area was significantly lower in response to vegetation restoration, particularly for NF compared to the CK $(p<0.05)$. This showed that vegetation restoration could slow the migration of DOC to some extent. This could be because of the higher litter inputs in NF and BP than that in the CK, and decomposed litter add DOC to the surface soil. Moreover, litter's runoff interception function can reduce the migration of DOC (Ma et al., 2016b). EOC refers to the part of SOC that can be oxidized by $330 \mathrm{mmol} / \mathrm{L}$ potassium permanganate (Neff and Asner, 2001; Von Lützow et al., 2007). In NF, BP, and CK, the distribution trends of EOC/SOC along the slopes were fundamentally identical: EOC/SOC was identical in the stable and sedimentary areas and slightly exceeded that in the eroded area. No significant $(p<0.05)$ enrichment trend in EOC was found in the sedimentary area, which Doetterl et al. (2012) also reported for cropland in central Belgium. It has been suggested that most of the EOC may have been mineralized during the migration process (Zhou et al., 2005; Ma et al., 2016a). In the 0-10 cm layer in both NF and BP, the EOC/SOC ratios in the stable and the sedimentary areas were significantly higher $(p<0.05)$ than that in the eroded area. However, there was no significant difference among the three areas in the CK $(p<0.05)$. This indicated that vegetation restoration could reduce topsoil mineralization during erosion to some extent.

Several studies have concluded that the SOC is more active in the foothills than in other areas (Doetterl et al., 2012; Zhang et al., 2019), although naturally, anthropogenic effects can introduce some variability in this final result. However, this study did not find any significant enrichment of labile organic carbon in the sedimentary area. This may be because the active components in 
organic carbon have been mineralized already during the migration process, or they may have migrated to deeper soil layers because of leaching (Wang et al., 2015; Kelleway et al., 2016).

This research concerns soil, and therefore in the future, more aspects related to the lack of clear information about the way soil properties affect (strongly in some cases) the process of soil organic matter (SOM) mineralization and its transformation should be included. For example, the potential presence of redox traces in soil (which is likely in soils at the bottom part of the slope) would indicate the contribution to the SOM mineralization of conditions other than simply erosion or vegetation. Another soil process could be related to soil oxygenation conditions and thus the conditions for SOM mineralization as well. In this research, we did not include information about the activity of soil fauna, but it could be an interesting line of future research because even earthworms can change the distribution of SOM (and also SOC) in soil significantly.

\section{Schematic Diagram of SOC Cycle Patterns on Hillslopes}

Since Doetterl et al. (2012); Doetterl et al. (2016) proposed agricultural land slopes' effect on SOC content and its stability explicitly, several models and regional organic carbon estimates have introduced topographic factors (Bloom et al., 2016; Fissore et al., 2017; Patton et al., 2019). Therefore, a model for the process of SOC migration on the slope was proposed in this study. SOC reserves depend mainly on a dynamic balance between input and output (Bloom et al., 2016; Vos et al., 2019), as indicated in Figure 6A. According to the findings of this study, SOC also migrated and redistributed within the soil slope system, as shown in Figure 6B. In stable areas, topographic factors affected SOC less and the input and output along the slope were both very small. In the vertical direction, the litter vegetation produced increased the SOC input and improved the SOC activity to some extent. The activated SOC was mineralized and then either degassed in the form of carbon dioxide or continued to migrate to lower layers because of leaching. However, stable organic carbon is stored in the soil for a long period. In the eroded area, SOC will migrate downward together with the eroded soil because of the slope. Therefore, for a specific area, SOC input and output will increase simultaneously. In the vertical direction, the vegetation-induced organic carbon input remains largely the same as in the stable area; however, soil erosion will intensify the labile organic carbon's mineralization and leaching, thus causing organic carbon to decrease continuously during its downward migration. In the sedimentary area, the eroded soil is deposited and the SOC content increases in response. However, the primary component is stable organic carbon. The reason may be that most of the labile organic carbon either has been mineralized during the migration process or could not be enriched in the sedimentary area because of leaching. However, the CK's slope migration and conversion process differed notably from that of the BP and NF. On the one hand, the SOC input on arable land is relatively small and crop yield increases the SOC output, thus decreasing the total SOC on the slope (Von Lützow et al., 2006; Vos et al., 2019). On the other hand, because of the decreased coverage with surface litter and low content of labile organic carbon, a large amount of SOC migrates downward from the eroded area because of soil erosion and finally deposits in the sedimentary area.

Finally, we agree strongly that erosion changes the soil and affects its morphology, properties, and taxonomic position. It cannot be assumed that the same soil will be everywhere, but we consider that although other soils occur in each of the transect sections studied, which is attributable to erosion and other processes in the past, as well as different water-air conditions in the soil, our results correspond to the most representative possible patterns according to the number of soil surface samples and low variability.

\section{CONCLUSION}

To examine vegetation restoration's effects on SOC redistribution along a loessial hillslope, soil samples were collected from stable, eroding, and sedimentary areas of typical hillslopes with different vegetation types in the hilly-gully loess area of China. Our results demonstrated that, compared to croplands, the differences in SOC content among these three areas decreased in NF and the BP, and the proportion of labile carbon to total SOC increased significantly for DOC/COC, but not for EOC/DOC. We conclude that this could indicate that vegetation restoration in the typical Loess Plateau hillslopes (NF in particular) is an effective measure to alleviate SOC's redistribution and spatial heterogeneity and reduce soil erosion, which directly affects other ecosystem services. Therefore, the effect of vegetation recovery considering the vegetation type should be taken into account to better estimate the soil carbon storage and evaluate ecosystem services in the sloping areas of the Loess Plateau in China.

\section{DATA AVAILABILITY STATEMENT}

The original contributions presented in the study are included in the article/Supplementary Material; further inquiries can be directed to the corresponding author.

\section{AUTHOR CONTRIBUTIONS}

YL finished the data curation and formal analysis and wrote the original draft. $\mathrm{TZ}$ played a guiding role in conceptualizing the field experiment, review, and editing the manuscript. XL and XZ assisted in data analysis and sample collection.

\section{FUNDING}

This work was supported by the state-supporting technology project in the 12th Five Year Plan (2015BAD07B030302).

\section{ACKNOWLEDGMENTS}

Special thanks go to Editor World LLC for English language editing. The authors thank the editor and the anonymous reviewers for helpful comments and suggestions during the review process. 


\section{REFERENCES}

Álvaro-Fuentes, J., Plaza-Bonilla, D., Arrúe, J. L., Lampurlanés, J., and CanteroMartínez, C. (2014). Soil organic carbon storage in a no-tillage chronosequence under Mediterranean conditions. Plant Soil 376, 31-41. doi:10.1007/s11104012-1167-X

Abdalla, M., Hastings, A., Chadwick, D. R., Jones, D. L., Evans, C. D., Jones, M. B., et al. (2018). Critical review of the impacts of grazing intensity on SOC storage and other soil quality indicators in extensively managed grasslands. Agric. Ecosyst. Environ. 253, 62-81. doi:10.1016/j.agee.2017.10.023

Bao, S. (2000). Soil Agrochemical analysis. Beijing: China Agriculture Press.

Beguería, S., Angulo-Martínez, M., Gaspar, L., and Navas, A. (2015). Detachment of SOC by rainfall splash: experimental assessment on three agricultural soils of Spain. Geoderma 245-246, 21-30. doi:10.1016/j.geoderma.2015.01.010

Berhe, A. A., and Torn, M. S. (2017). Erosional redistribution of topsoil controls soil nitrogen dynamics. Biogeochemistry 132, 37-54. doi:10.1007/s10533-0160286-5

Blaire, G. J., Lefroy, R. D., and Lisle, L. (1995). Soil carbon fractions based on their degree of oxidation, and the development of a carbon management index for agricultural systems. Crop Pasture Sci. 46, 1459-1466. doi:10.1071/AR9951459

Bloom, A. A., Exbrayat, J., van der Velde, I. R., Feng, L., and Williams, M. (2016). The decadal state of the terrestrial carbon cycle: global retrievals of terrestrial carbon allocation, pools, and residence times. Proc. Natl. Acad. Sci. Unit. States Am. 113, 1285-1290. doi:10.1073/pnas.1515160113

Brevik, E. C., Slaughter, L., Singh, B. R., Steffan, J. J., Collier, D., Barnhart, P., et al. (2020). Soil and human health: current status and future needs. Air Soil. Water Res. 13, 1178622120934441. doi:10.1177/1178622120934441

Cagnarini, C., Blyth, E., Emmett, B. A., Evans, C. D., Griffiths, R. I., and Keith, A. (2019). Zones of influence for soil organic matter dynamics: a conceptual framework for data and models. Global Change Biol. 25, 3996-4007. doi:10. $1111 /$ gcb. 14787

Ceccon, C., Panzacchi, P., Scandellari, F., Prandi, L., Ventura, M., Russo, B., et al. (2011). Spatial and temporal effects of soil temperature and moisture and the relation to fine root density on root and soil respiration in a mature apple orchard. Plant Soil 342, 195-206. doi:10.1007/s11104-010-0684-8

Cerdà, A., and Rodrigo-Comino, J. (2020). Is the hillslope position relevant for runoff and soil loss activation under high rainfall conditions in vineyards? Ecohydrol. Hydrobiol. 20, 59-72. doi:10.1016/j.ecohyd.2019.05.006

Chang, R., Fu, B., Liu, G., and Liu, S. (2011). Soil carbon sequestration potential for "Grain for green" project in Loess Plateau, China. Environ. Manage. 48, 1158-1172. doi:10.1007/s00267-011-9682-8

Doetterl, S., Berhe, A. A., Nadeu, E., Wang, Z., Sommer, M., and Fiener, P. (2016). Erosion, deposition and soil carbon: a review of process-level controls, experimental tools and models to address $\mathrm{C}$ cycling in dynamic landscapes. Earth Sci. Rev. 154, 102-122. doi:10.1016/j.earscirev.2015.12.005

Doetterl, S., Six, J., Wesemael, B. V., and Van Oost, K. (2012). Carbon cycling in eroding landscapes: geomorphic controls on soil organic $\mathrm{C}$ pool composition and C stabilization. Global Change Biol. 18, 2218-2232. doi:10.1111/j.13652486.2012.02680.x

Feng, X., Fu, B., and Lu, N. (2013). How ecological restoration alters ecosystem services: an analysis of carbon sequestration in China's Loess Plateau. Sci. Rep. 3, 2846. doi:10.1038/srep02846

Fissore, C., Dalzell, B. J., Berhe, A. A., Voegtle, M., Evans, M., and Wu, A. (2017). Influence of topography on soil organic carbon dynamics in a Southern California grassland. Catena 149, 140-149. doi:10.1016/j.catena.2016.09.016

Franzluebbers, A. J. (2002). Soil organic matter stratification ratio as an indicator of soil quality. Soil Res. 66, 95-106. doi:10.1016/S0167-1987(02)00018-1

García-Díaz, A., Allas, R. B., Gristina, L., Cerdà, A., Pereira, P., and Novara, A. (2016). Carbon input threshold for soil carbon budget optimization in eroding vineyards. Geoderma 271, 144-149. doi:10.1016/j.geoderma.2016.02.020

García-Díaz, A., Marqués, M. J., Sastre, B., and Bienes, R. (2018). Labile and stable soil organic carbon and physical improvements using groundcovers in vineyards from central Spain. Sci. Total Environ. 621, 387-397. doi:10.1016/ j.scitotenv.2017.11.240

Grebliunas, B. D., Armstrong, S. D., and Perry, W. L. (2016). Changes in waterextractable organic carbon with cover crop planting under continuous corn silage production. Air Soil. Water Res. 9, 45. doi:10.4137/aswr.s30708
Haigh, M., Desai, M., Cullis, M., D’Aucourt, M., Sansom, B., Wilding, G., et al. (2019). Composted municipal green waste enhances tree success in opencast coal land reclamation in Wales. Air Soil. Water Res. 12, 1178622119877837. doi:10.1177/1178622119877837

Hancock, G. R., Kunkel, V., Wells, T., and Martinez, C. (2019). Soil organic carbon and soil erosion-Understanding change at the large catchment scale. Geoderma 343, 60-71. doi:10.1016/j.geoderma.2019.02.012

Haynes, R. J. (2005). Labile organic matter fractions as central components of the quality of agricultural soil: an overview. Adv. Agron. 85, 221-268. doi:10.1016/ S0065-2113(04)85005-3

IUSS Working Group (2006). World reference Base for soil Resources. World soil resources reports No. 103, Rome: The International Union of Soil Science.

Jenny, H. (1994). Factors of soil formation. A system of quantitative pedology. New York: Dover Publications.

Kelleway, J. J., Saintilan, N., Macreadie, P. I., and Ralph, P. J. (2016). Sedimentary factors are key predictors of carbon storage in SE Australian Saltmarshes. Ecosystems 19, 865-880. doi:10.1007/s10021-016-9972-3

Kiani-Harchegani, M., and Sadeghi, S. H. (2020). Practicing land degradation neutrality (LDN) approach in the Shazand Watershed, Iran. Sci. Total Environ. 698, 134319. doi:10.1016/j.scitotenv.2019.134319

Kim, D., and Kirschbaum, M. U. F. (2015). The effect of land-use-change on the net exchange rates of greenhouse gases: a compilation of estimates. Agric. Ecosyst. Environ. 208, 114-126. doi:10.1016/j.agee.2015.04.026

Kirkels, F. M. S. A., Cammeraat, L. H., and Kuhn, N. J. (2014). The fate of soil organic carbon upon erosion, transport and deposition in agricultural landscapes-A review of different concepts. Geomorphology 226, 94-105. doi:10.1016/j.geomorph.2014.07.023

Lavelle, P. (1988). Earthworm activities and the soil system. Biol. Fert. Soils 6, 237-259. doi:10.1007/BF00260820

Li, T., Zhang, H., Wang, X., Cheng, S., Fang, H., and Liu, G. (2019). Soil erosion affects variations of soil organic carbon and soil respiration along a slope in Northeast China. Ecol. Processes 8, 28. doi:10.1186/s13717-019-0184-6

Ma, H., Yang, X., Guo, Q., Zhang, X., and Zhou, C. (2016a). Soil organic carbon pool along different altitudinal level in the Sygera Mountains, Tibetan Plateau. J. Mt. Sci. 13, 476-483. doi:10.1007/s11629-014-3421-6

Ma, W., Li, Z., Ding, K., Huang, B., Nie, X., and Lu, Y. (2016b). Soil erosion, organic carbon and nitrogen dynamics in planted forests: a case study in a hilly catchment of Hunan Province, China. Soil Res. 155, 69-77. doi:10.1016/j. still.2015.07.007

Muñoz-Rojas, M., Erickson, T. E., Dixon, K. W., and Merritt, D. J. (2016). Soil quality indicators to assess functionality of restored soils in degraded semiarid ecosystems. Restor. Ecol. 24, S43-S52. doi:10.1111/rec.12368

Neff, C. N., and Asner, G. P. (2001). Dissolved organic carbon in terrestrial ecosystems: synthesis and a model. Ecosystems 4, 29-48. doi:10.1007/ s100210000058

Novara, A., Pulido, M., Rodrigo-Comino, J., Prima, S. D., Smith, P., Gristina, L., et al. (2019). Long-term organic farming on a citrus plantation results in soil organic carbon recovery. Cuadernos de Investigación Geográfica 45, 271-286. doi:10.18172/cig.3794

Olson, K. R., and Gennadiev, A. N. (2020). Dynamics of soil organic carbon storage and erosion due to land use change (Illinois, USA). Eurasian Soil Sci. 53, 436-445. doi:10.1134/S1064229320040122

Patton, N. R., Lohse, K. A., Seyfried, M. S., Godsey, S. E., and Parsons, S. B., (2019) Topographic controls of soil organic carbon on soil-mantled landscapes. Sci. Rep. 9,6390. doi:10.1038/s41598-019-42556-5

Perakis, S. S., and Hedin, L. O. (2002). Nitrogen loss from unpolluted South American forests mainly via dissolved organic compounds. Nature 416-419. doi:10.1038/415416a

Pereira, P., Barcelo, D., and Panagos, P. (2020). Soil and water threats in a changing environment. Environ. Res. 186, 109501. doi:10.1016/j.envres.2020.109501

Pereira, P., Bogunovic, I., Munoz-Rojas, M., and Brevik, E. (2018). Soil ecosystem services, sustainability, valuation and management. Curr. Opin. Environ. Sci. Heal. 5, 7-13. doi:10.1016/j.coesh.2017.12.003

Petrakis, R. E., Norman, L. M., Lysaght, O., Sherrouse, B. C., Semmens, D., Bagstad, K. J., et al. (2020). Mapping perceived social values to support a respondent-defined restoration economy: case study in Southeastern Arizona, USA. Air Soil. Water Res. 13, 1178622120913318. doi:10.1177/ 1178622120913318 
Qin, Y., Xin, Z., Yu, X., and Xiao, Y. (2014). Influence of vegetation restoration on topsoil organic carbon in a small catchment of the Loess Hilly Region, China. PloS One 9 (6), e94489. doi:10.1371/journal.pone.0094489

Ran, L., Lu, X., and Xu, J. (2013). Effects of vegetation restoration on soil conservation and sediment loads in China: a critical review. Crit. Rev. Environ. Sci. Technol. 43, 1384-1415. doi:10.1080/10643389.2011.644225

Rodrigo-Comino, J., López-Vicente, M., Kumar, V., Rodríguez-Seijo, A., Valkó, O., Rojas, C., et al. (2020). Soil science challenges in a new era: a transdisciplinary overview of relevant topics. Air Soil. Water Res. 13, 1178622120977491. doi:10. $1177 / 1178622120977491$

Rodrigo-Comino, J., Ruiz Sinoga, J. D., Senciales González, J. M., Guerra-Merchán, A., Seeger, M., and Ries, J. B. (2016). High variability of soil erosion and hydrological processes in Mediterranean hillslope vineyards (Montes de Málaga, Spain). Catena 145, 274-284. doi:10.1016/j.catena.2016.06.012

Rodrigo-Comino, J., Senciales, J. M., Ramos, M. C., Martínez-Casasnovas, J. A., Lasanta, T., Brevik, E. C., et al. (2017). Understanding soil erosion processes in Mediterranean sloping vineyards (Montes de Málaga, Spain). Geoderma 296, 47-59. doi:10.1016/j.geoderma.2017.02.021

Sanderman, J., and Chappell, A. (2013). Uncertainty in soil carbon accounting because of unrecognized soil erosion. Global Change Biol. 19, 264-272. doi:10.1111/gcb.12030

Shi, P., Zhang, Y., Li, P., Li, Z., Yu, K., Ren, Z., et al. (2019a). Distribution of soil organic carbon impacted by land-use changes in a hilly watershed of the loess plateau, China. Sci. Total Environ. 652, 505-512. doi:10.1016/j.scitotenv.2018.10.172

Shi, P., Zhang, Y., Yu, Y., Li, P., Li, Z., Xiao, L., et al. (2019b). Land-use types and slope topography affect the soil labile carbon fractions in the loess hilly-gully area of Shaanxi, China. Arch. Agron. Soil Sci. 66, 638-650. doi:10.1080/03650340.2019.1630824

Sun, W., Guo, S., and Song, X. (2010). Effects of topography and land use on spatial distribution of topsoil organic carbon in loess hilly-gully region. J. Nat. Resour. 3, 443-453. doi:10.1016/S1875-2780(09)60057-2

van der Bank, M., and Karsten, J. (2020). Climate change and South Africa: a critical analysis of the earthlife and the drive for concrete climate practices. Air Soil. Water Res. 13, 1178622119885372. doi:10.1177/1178622119885372

Von Lützow, M., Kögel-knabner, I., Ekschmitt, K., Flessa, H., Guggengerger, G., Matzner, E., et al. (2007). SOM fractionation methods: relevance to functional pools and to stabilization mechanisms. Soil Biol. Biochem. 39, 2183-2207. doi:10.1016/j.soilbio.2007.03.007

Von Lützow, M., Kögel-knabner, I., Ekschmitt, K., Matzner, E., Guggengerger, G., Marschner, B., et al. (2006). Stabilization of organic matter in temperate soils: mechanisms and their relevance under different soil conditions-A review. Eur. J. Soil Sci. 57, 426-445. doi:10.1111/j.1365-2389.2006.00809.x

Vos, C., Don, A., Hobley, F. U., Prietz, R., Heidkamp, M., and Freibauer, A. (2019). Factors controlling the variation in organic carbon stocks in agricultural soils of Germany. Eur. J. Soil Sci. 70, 550-564. doi:10.1111/ejss.12787

Wang, X., Cammeraat, E. L. H., Cerli, C., and Kalbitz, K. (2014b). Soil aggregation and the stabilization of organic carbon as affected by erosion and deposition. Soil Biol. Biochem. 72, 55-65. doi:10.1016/j.soilbio.2014.01.018

Wang, X., Cammeraat, E. L. H., Romeijn, P., and Kalbitz, K. (2014a). Soil organic carbon redistribution by water erosion-the role of $\mathrm{CO}_{2}$ emissions for the carbon budget. PloS One 9, e96299. doi:10.1371/journal.pone.0096299

Wang, X., Jelinski, N. A., Toner, B., and Yoo, K. (2019). Long-term agricultural management and erosion change soil organic matter chemistry and association with minerals. Sci. Total Environ. 648, 1500-1510. doi:10.1016/j.scitotenv.2018.08.110

Wang, Y., Fu, B., Lü, Y., and Chen, L. (2011). Effects of vegetation restoration on soil organic carbon sequestration at multiple scales in semi-arid Loess Plateau, China. Catena 85, 58-66. doi:10.1016/j.catena.2010.12.003

Wang, Y., Shao, M., Zhang, C., Liu, Z., Zou, J., and Xiao, J. (2015). Soil organic carbon in deep profiles under Chinese continental monsoon climate and its relations with land uses. Ecol. Eng. 361-367. doi:10.1016/j.ecoleng.2015.05.004

Wang, Z., Hu, Y., Wang, R., Guo, S., Du, L., and Zhao, M. (2017). Soil organic carbon on the fragmented Chinese Loess Plateau: combining effects of vegetation types and topographic positions. Soil Res. 174, 1-5. doi:10.1016/j.still.2017.05.005

Wiaux, F., Cornelis, J. T., Cao, W., Vanclooster, M., and Van Oost, K. (2014). Combined effect of geomorphic and pedogenic processes on the distribution of soil organic carbon quality along an eroding hillslope on loess soil. Geoderma 216, 36-47. doi:10.1016/j.geoderma.2013.10.013

Wiesmeier, M., Urbanski, L., Hobley, E., Lang, B., von Lützow, M., Marin-Spiotta, E., et al. (2019). Soil organic carbon storage as a key function of soils-a review of drivers and indicators at various scales. Geoderma 333, 149-162. doi:10.1016/j. geoderma.2018.07.026

Willaarts, B. A., Oyonarte, C., Muñoz-Rojas, M., Ibáñez, J. J., and Aguilera, P. A. (2016). Environmental factors controlling soil organic carbon stocks in two contrasting Mediterranean climatic areas of southern Spain. Land Degrad. Dev. 27, 603-611. doi:10.1002/ldr.2417

Xin, Z., Qin, Y., and Yu, X. (2016). Spatial variability in soil organic carbon and its influencing factors in a hilly watershed of the Loess Plateau, China. Catena 137, 660-669. doi:10.1016/j.catena.2015.01.028

Yeasmin, S., Jahan, E., Molla, M., Islam, A. K. M., Anwar, M., Or Rashid, M., et al. (2020). Effect of land use on organic carbon storage potential of soils with contrasting native organic matter content. International Journal of Agronomy 2020, 1-9. doi:10.1155/2020/8042961

Yu, H., Zha, T., Zhang, X., and Ma, L. (2019a). Vertical distribution and influencing factors of soil organic carbon in the Loess Plateau, China. Sci. Total Environ. 693, 133632. doi:10.1016/j.scitotenv.2019.133632

Yu, Y., Wei, W., Chen, L., Feng, T., and Daryanto, S. (2019b). Quantifying the effects of precipitation, vegetation, and land preparation techniques on runoff and soil erosion in a Loess watershed of China. Sci. Total Environ. 625, 755-764. doi:10.1016/j.scitotenv.2018.10.255

Yu, H., Zha, T., Zhang, X., Nie, L., Ma, L., and Pan, Y. (2020a). Spatial distribution of soil organic carbon may be predominantly regulated by topography in a small revegetated watershed. Catena 188, 104459. doi:10. 1016/j.catena.2020.104459

Yu, Y., Zhao, W., Martinez-Murillo, J. F., and Pereira, P. (2020b). Loess Plateau: from degradation to restoration. Sci. Total Environ. 738, 140206. doi:10.1016/j. scitotenv.2020.140206

Yu, Y., Wei, W., Chen, L., Feng, T., Daryanto, S., and Wang, L. (2016). Land preparation and vegetation type jointly determine soil conditions after longterm land stabilization measures in a typical hilly catchment, Loess Plateau of China. J. Soils Sediments 17, 144-156. doi:10.1007/s11368-016-1494-2

Zhang, C., Liu, G., Xue, S., and Sun, C. (2013a). Soil organic carbon and total nitrogen storage as affected by land use in a small watershed of the Loess Plateau, China. Eur. J. Soil Biol. 54, 16-24. doi:10.1016/j.ejsobi.2012.10.007

Zhang, S., Zhang, A., Meng, X., and Yin, H. (2013b). Evaluation of soil erosion sensitivity in Jixian County, Shanxi Province based on ecological immigrants. Soil Water Conser. China 8, 61-63. doi:10.14123/j.cnki.swcc.2013.08.023

Zhang, H., Huang, Y., An, S., and Xin, X. (2003). Soil active organic carbon under forest communities in the Loess Plateau. Res. Soil Water Conser. 3, 65-70.

Zhang, X., Yang, Z., Zha, T., Zhang, Z., Wang, G., Zhu, Y., et al. (2017). Changes in the physical properties of soil in forestlands after 22 years under the influence of the Conversion of Cropland into Farmland Project in Loess region, Western Shanxi Province. Acta Ecol. Sin. 37 (2), 416-424. doi:10.5846/stxb201507291596

Zhang, Y., Li, P., Lie, X., Zhao, B., and Peng, S. (2019). Effects of topography and land use on soil organic carbon in hilly region of Loess Plateau. Acta Pedol. Sin. 56 (5) 1140-1149. doi:10.11766/trxb201901220367

Zhou, L., Li, B., and Zhou, G. (2005). Advances in controlling factors of soil organic carbon. Adv. Earth Sci. 20, 99-105.

Zhou, Z., Zhang, Z., Zha, T., Luo, Z., Zheng, J., and Sun, O. (2013). Predicting soil respiration using carbon stock in roots, litter and soil organic matter in forests of Loess Plateau in China. Soil Biol. Biochem. 57, 135-143. doi:10.1016/j.soilbio. 2012.08.010

Conflict of Interest: Author XZ was employed by company The Third Construction Co., Ltd. of China Construction First Group.

The remaining authors declare that the research was conducted in the absence of any commercial or financial relationships that could be construed as a potential conflict of interest.

Copyright (c) 2021 Liang, Li, Zha and Zhang. This is an open-access article distributed under the terms of the Creative Commons Attribution License (CC BY) The use, distribution or reproduction in other forums is permitted, provided the original author(s) and the copyright owner(s) are credited and that the original publication in this journal is cited, in accordance with accepted academic practice. No use, distribution or reproduction is permitted which does not comply with these terms. 